There are few jurisdictions totally uncommitted to the illegal-per-se rule. In other states the law does not expressly require that public contracts in which an official is privately interested automatically be held void. Where precedent allows some freedom in dealing with the question and where legislative reexamination is possible, ${ }^{58}$ public policy would best be served by embracing a rule which, while preserving the in terrorem effect of the illegal-per-se rule, is more sensitive to the peculiarities of enforcement and not oblivious to the possibilities of good faith in the premises.

Reasonable Doubt in Civil and Criminal Laws, $10 \mathrm{Am}$. L. Rev. 642 (1875). The use of the criminal standard in this instance would be a complete innovation because the opponent, and not the proponent, of the issue of illegality would have to sustain this burden.

${ }^{58} \mathrm{As}$ to whose function it is to determine "public policy," compare these two contradictory statements: "[W] hen a court holds that a contract is valid or invalid, because it is or is not 'against public policy'... the question of what sound policy requires is plainly a judicial question"; 6 Corbin, Contracts $\$ 1375$ (1951); and "What does or does not represent the general interest is for the legislature to determine." Gellhorn, op. cit. supra note 13, at 685 . Generally, as to the function of the court in interpreting a statute that determines public policy, see Mr. Justice Frankfurter dissenting in United States v. Atlantic Mutual Ins. Co., 343 U.S. 236, 242 (1952).

\title{
VALUATION IN CONDEMNATION: THE TWIN CITY POWER CASE
}

In condemnation proceedings the Fifth Amendment" requirement of "just compensation" has generally been interpreted to be the market value at the time of taking. ${ }^{2}$ In the recent case of United States v. Twin City Power Co., ${ }^{3}$ the Supreme Court, in a five to four decision, departed from this standard in holding that the increment in the value of riparian lands due to their suitability as a power site was not compensable when the United States was the condemnor. The majority opinion contains no reference to market value, or to any other standard, and the issue is stated simply in terms of whether or not the "United States must pay ... the value of the land as a site for hydroelectric power operations."4

In reaching its decision, the Court relied solely on United States v. ChandlerDunbar Co. ${ }^{5}$ which was a condemnation proceeding brought by the United

1 U.S. Const. Amend. 5.

2 Consult 4 Nichols, Eminent Domain $\$ 12.1$ (3d ed., 1951); 1 Orgel, Valuation under Eminent Domain $\$ 17$ (2d ed., 1953), and cases there cited.

3350 U.S. 222 (1956).

4 Tbid., at 223.

5229 U.S. 53 (1913). In its brief the government also relied on three lawer court cases. Washington Water Power Co. v. United States, 135 F.2d 541 (C.A. 9th, 1943); Continental Land Co. v. United States, 88 F.2d 104 (C.A. 9th, 1937); United States v. West Virginia Power Co., 56 F.Supp. 298 (S.D. W.Va., 1944). The first two cases can be read, however, to fall within the established doctrine that compensation will not be allowed for uses which are too remote or speculative. 
States to acquire land adjoining the St. Marys River in Michigan. The company claimed that because its title under Michigan law included the bed of the river to the thread of the stream, it owned the river and the inherent power in the falls and rapids, subject only to the public right of navigation. The lower court awarded the company $\$ 550,000.00$ for the value of what it called "raw water" flowing over the bed. The Supreme Court reversed, stating that the flow of the stream was in no sense private property and therefore was not compensable. The Court also sustained the government's exceptions to allowing an increment in the value of the fast land due to its suitability as a factory site in connection with the development of water power, because 'these 'additional' values were based upon the erroneous hypothesis that the company had a private property interest in the water power of the river." ${ }^{36}$ However, the government's exceptions to the values based upon the availability of the land for lock and canal purposes were overruled.

There is no reasonable basis for distinguishing between value for factory site purposes and value for lock and canal purposes. Both uses involved the utilization of the water and the placing of obstructions therein, in one case a dam, in the other a set of locks. In either situation, the obstructions were subject to removal upon a determination that they constituted a hindrance to navigation. Nor can a distinction be drawn on the basis of the government's power to grant or withhold the right to use the stream for water power purposes, because under the statute in effect at that time ${ }^{7}$ a license was required to build a canal or lock as well as a dam.

This contradiction in the awards makes Chandler-Dunbar, at best, equivocal authority and is the reason that the case was cited by both the majority and the minority in the Twin City case. Mr. Justice Douglas, writing for the majority, relied on the Court's refusal of any compensation for factory site value, while Mr. Justice Burton, writing for the dissenters, relied on the affirmation of the lock and canal award. Douglas relegated the discussion of the lock and canal award to a footnote in which it is asserted that a possible explanation of this award is "the fact that, on the special facts of the case, the use of the land for canals and locks was wholly consistent with the dominant navigation servitude of the United States and indeed aided navigation." 8 But to be consistent in this argument Douglas would have to say that whenever a dam which a private company intended to build would aid navigation, or, at the very least, would not have hindered it, then the government in condemnation proceedings would have to pay the power site value. There is no language in the Twin City opinion to indicate that the majority would be willing to make such a distinction. Douglas admits the weakness of this argument by his later statement that "[w] hatever may be said for that phase of the case, it affords no support for re-

6 United States v. Chandler-Dunbar Co., 229 U.S. 53, 75 (1913).

${ }^{7} 26$ Stat. 426, 454 (1890). Consult also 30 Stat. 1151, 1155 (1899).

8 United States v. Twin City Power Co., 350 U.S. 222, 226-27 (1956). 
spondent, since water-power value, held to be compensable by the Court of Appeals, was ruled to be noncompensable in the Chandler-Dunbar case."

Mr. Justice Burton, in writing the Twin City dissent, attempted to explain the inconsistency in Chandler-Dunbar by stating that the refusal of additional compensation for the land because of its suitability as a factory site in connection with the development of water power was "due to the speculative nature of the proposed use."10 There is some plausibility in this argument because the Chandler-Dunbar Court, in upholding the lock and canal award, had said that the possibility of such a use "had passed beyond the region of the purely conjectural or speculative."11 However, this statement was not made to distinguish the lock and canal claim from the factory site claim but was addressed to the general rule that compensation cannot be had for uses which are purely conjectural or speculative in nature. The real basis of the refusal of the factory site award can be seen in the Court's unequivocal statement, which is quoted by Douglas, that "[t]he Government had dominion over the water power of the rapids and falls and cannot be required to pay any hypothetical additional value to a riparian owner who had no right to appropriate the current to his own commercial use." 12

Thus, upon close examination, both explanations fail to reconcile the holdings in the Chandler-Dunbar case. A possible explanation for these irreconcilable holdings is that, because water power is a common subject matter, the Court carried over to the factory site claim the same reasoning it had used in refusing the company's peculiar claim of ownership in the "raw water." It will be recalled that Chandler-Dunbar's claim was that, because of its ownership of the fast land, it owned the river and the inherent power in the falls and rapids, and that the river and water power had a value independent of the value of the fast lands. The Court, in denying any increment in the value of the fast lands in connection with the factory site claim, referred back to its refusal of the "raw water" claim and said:

- Having decided that the Chandler-Dunbar Company as riparian owners had no such vested property right in the water power inherent in the falls and rapids of the river, and no right to place in the river the works essential to any practical use of the flow of the river, the Government cannot be justly required to pay for an element of value which did not inhere in these parcels as upland. The Government has dominion over the water power in the rapids and falls and cannot be required to pay any hypothetical additional value to a riparian owner who had no right to appropriate the current to his own commercial use. ${ }^{13}$

It is difficult to understand how the common subject matter of water power, by itself, can justify similar treatment of "raw water" and factory site claims. The factory site claim is much more like the lock and canal claim in that both are

\footnotetext{
${ }^{9}$ Ibid., at 227.

${ }^{10} \mathrm{Ibid}$, at 245.

11 United States v. Chandler-Dunbar Co., 229 U.S. 53, 77 (1913).

12 Ibid., at 76.

${ }^{13}$ Ibid.
} 
based on an alleged increment in the value of riparian land due to a prospective use of the stream-a use which the government could have granted or withheld in either case.

The fallacy of the Court's reasoning in not distinguishing the "raw water" and factory site claims can be seen by comparing the condemnation of land adjacent to a public highway. If the owner claimed compensation for the value of the highway based on his ownership of the fee of the land underneath the pavement, his claim would properly be denied. If it could be shown, however, that the adjacent land had a high market value based on suitability as a gas station site, the owner would hardly be denied this value on the theory that it had already been shown that he had no compensable interest in the highway.

In refusing the "raw water" award, the Court not only denied ChandlerDunbar's ownership of the water, but it also talked in terms of the government's power to withhold the right of the riparian owner to use the flow of the stream. This was not, however, an independent ground for refusing the award. It was used primarily to reject the claim of property in the water, on the theory that the federal government's control over use of the stream prevented Michigan law as to ownership of the bed of the stream from giving property rights, against the federal government, in the stream itself.

If the above analysis of Chandler-Dunbar is correct, then the holding on the factory site claim becomes very weak authority for Douglas' position in the Twin City case. The result is that the claim before the Twin City Court was in effect a new question because Twin City was claiming an increment in the value of its fast lands and not ownership of the stream itself. The Chandler-Dunbar case was in reality only a decision on the latter point which was applied, by oversimplified reasoning, to the valuation of the fast lands in connection with the factory site claim.

The language of the majority opinion in the Twin City case is ambiguous. The case can be interpreted broadly as holding that, because of its power over navigable streams, the government need not pay a riparian landowner any increment of value that is due to the flow of the stream. It may be read more narrowly, that such value need not be paid only when the riparian land is condemned for purposes that will aid navigation. The former view is illustrated by the last sentences of the opinion:

If the owner of the fast lands can demand water-power value as part of his compensation, he gets the value of a right that the Government in the exercise of its dominant servitude can grant or withhold as it chooses. The right has value or is an empty one dependent solely on the Government.... To require the United States to pay for this water-power value would be to create private claims in the public domain.14

Mr. Justice Douglas' idea that compensation for water-power value creates "private claims in the public domain" is unique in condemnation law. This can

14 United States v. Twin City Power Co., 350 U.S. 222, 228 (1956). 
be more clearly seen by statement of the converse: No compensation need be given for any value which is derived from property in which a condemnee has no private claim. This means that the condemnee-owner of land at the intersection of two federal highways need not be paid gas-station-site value because he has no private claim in the highway, which would be the source of the value.

It might appear that this gas-station-site analogy is invalid because the increase in value there depends merely on the land being next to the highway, whereas the development of water power involves placing obstructions in, and physically utilizing, the stream. In order to show the invalidity of the distinction between "passive" and "active" use of adjoining property, the ultimate implications of the Trin City decision will be assumed, i.e., that the government owns the stream. The riparian owner who wished to build a dam would then, in effect, be seeking an easement in the stream and the question is whether or not the probabilities of obtaining such an easement can create compensable values for condemnation purposes..$^{15}$ Since compensation is allowed for value based on a probability of obtaining the ownership of other property ${ }^{16}$ it also should be allowed when all that is required is an easement..17

The narrower view, that water-power value is disallowed only when the land is condemned for purposes that will aid navigation, finds support in the fact that the Court went to great pains to show that the proposed government project would aid navigation. ${ }^{18}$ The only way in which the analysis of this view

${ }^{15}$ In valuing property the market does not distinguish between possible "passive" or "active" use of adjoining land except insofar as there might be a difference in the probabilities of effecting such use. Market value depends on the uses to which property is adaptable and does not reflect "rights" as much as probabilities. Twin City could have been denied waterpower value on the ground that the probability of obtaining a federal license to build a dam was so slight that any value based thereon was too speculative to be compensable. This was in effect what the government argued. Brief for United States at 35 et seq. But the Court did not decide Twin City on this ground, even though other cases have been so decided when the facts were no more favorable to such a decision than those in the principal case. United States ex rel. T.V.A. v. Powelson, 319 U.S. 266 (1943); Olson v. United States, 292 U.S. 246 (1934).

${ }^{16}$ See cases cited note 15 supra; 4 Nichols, Eminent Domain §12.314 (3d ed., 1951); McCormick, Damages §129 (1935).

${ }^{17}$ The Court also justified denying water-power value by saying that "[w] ment can grant or withhold and exploit for its own benefit has a value that is peculiar to it and that no other use enjoys." United States v. Twin City Power Co., 350 U.S. 222, 228 (1956). This should not be interpreted as a separate grounds for denial of compensation, but, as in Chandler-Dunbar (consult discussion at 373 supra) simply as part of the rationale leading to the conclusion that the government has a superior property right in the stream, against which the riparian owner can assert no "private claim." But, as shown above, compensation cannot properly be denied because of lack of a "private claim" but should be made for the probability of using the adjoining property.

${ }^{18}$ Another view of the case makes the question of whether any increment of value that is due to the flow of the stream is to be paid or not turn solely on what is done to the stream. If the government, in the exercise of its navigation power, completely appropriates the flow of the stream, the increased value need not be paid no matter for what purposes the land is condemned. But if the stream has not been appropriated by the government then the increased value must be paid even if the land is condemned for purposes that will aid navigation. This interpretation bears more resemblance to the traditional market value standard than either 
could differ from that of the broad holding would be if the fact that the government, by an exercise of its power over navigable streams, could destroy the water-power value simultaneously with condemnation of the riparian land somehow justifies abandoning the market value standard for compensation in that condemnation. The Court reached the position that it did by reference to the fact that riparian landowners need not be compensated when they are required to remove obstructions from the stream or are denied use of the stream in some other way. These acts, of course, could not be done solely for the purpose of driving down the price of land with an eye toward later condemnation. ${ }^{19}$ But if they were done previously, for a reason which did not "involve an impossibility" in the aid of navigation, ${ }^{20}$ the government could then take the riparian land at the reduced value. This is so, however, only because withholding the use of the stream would be reflected in the market value of the riparian land-a value which would also reflect the probability that the government would renege and later allow a private company to use the stream for waterpower purposes. The validity of the argument thus depends on the market value standard-a standard which is completely repudiated by the conclusion which the argument purports to reach.

The decision seems to be based on the idea that value due to the probability that the stream will be used as a private power site is a value which inures to riparian owners only at the government's pleasure, and that they can be deprived of this value at any time without reference to the market value. In effect this means that the navigation power creates a superior property right in the government. That this is what the Court intended is shown by the statement:

The interest of the United States in the flow of a navigable stream originates in the Commerce Clause. That Clause speaks in terms of power, not of property. But the

of the other two. The market would reflect complete appropriation of the stream by placing a much lower value on riparian land. On the other hand, if the stream were not completely appropriated, the market would reflect the probabilities that it would be available to private companies for power site purposes. Admittedly this reading of Twin City is strained, but it provides a means to restrict this case and return to the more appropriate market value standard.

${ }^{19}$ See United States ex rel. T.V.A. v. Powelson, 319 U.S. 266, 284 (1943). This same principle has been applied in zoning cases where it appeared that the governmental authority zoned the land for the purpose of driving the value down with a view toward later condemnation proceedings. See, e.g., Robyns v, City of Dearborn, 341 Mich. 495, 67 N.W.2d 718 (1954); Long v. City of Highland Park, 329 Mich. 146, 45 N.W.2d 10 (1950); State ex rel. Scandrett v. Nelson, 240 Wis. 438, 3 N.W.2d 765 (1942); State ex rel. Tingley v. Gurda, 209 Wis. 63, 243 N.W. 317 (1932). As to the effect of zoning regulations on the market value, consult Zoning or Other Governmental Regulations as to Use of Property as a Factor in Determination of Damages in Eminent Domain, 173 A.L.R. 265 (1948), and cases there cited.

${ }^{20}$ Courts will not inquire into congressional determinations that a particular project will aid navigation unless that project "involves an impossibility" in the aid of navigation. See Old Dominion Land Co. v. United States, 269 U.S. 55 (1925), cited in United States v. Twin City Power Co., 350 U.S. 222, 224 (1956). 
power is a dominant one which can be asserted to the exclusion of any competing or conflicting one. The power is . . "a dominant servitude" . . "a superior navigation easement." $" 21$

Under this view of the case any time the government had the power to regulate use of property, that power would automatically create a property right in the government. Take, for example, land especially valuable as a site for a liquor store, which, of course, requires a state license. If the state decided to establish a system of state liquor stores it could take the land at a reduced price under the theory that, as to this use, its licensing power had given it a prior property right. This would apparently be the case even though the bill which provided for the licensing power was not intended to give the state any "property rights" but was intended only to allow regulation of certain types of commerce. Furthermore, since Douglas did not argue from the Federal Power Act, but directly from the Commerce Clause itself, presumably no enacting statute would be required. This rather surprising extension of regulatory powers is far beyond the originally intended scope of these powers. It is difficult to see what it accomplishes other than allowing the government to take certain lands at bargain prices.

As the Fifth Amendment proscribes the government from taking land at bargain prices so does the power of eminent domain, which inures in every sovereign, allow it to obtain needed land without paying a hold-up value. In an economy based on private enterprise the use of such extra-economic power should be exercised so that it has as little effect as possible on the workings of legitimate economic factors. This can only be done by application of the traditional market value standard. Continued application of the $T$ win City rule will not only discourage expenditures for private power development, but it will also place the cost of land acquisition for any power development on the present owners of suitable land rather than on consumers or taxpayers where the burden properly belongs.

${ }^{21}$ United States v. Twin City Power Co., 350 U.S. 222, 224-25 (1956).

\section{STRANGER ATTACK ON SISTER-STATE DECREES OF DIVORCE}

Perplexing doctrinal difficulties are presented by the problem of stranger ${ }^{1}$ attack $^{2}$ on sister-state decrees of divorce. Given a finding by the divorce court

"A "stranger" in this context is a third party who, though neither party nor privy, has some right or interest which is affected by the purported dissolution of a marital status; for example, a subsequent spouse, a legatee of a subsequent spouse, a tenant of a party, or a sister state in which a party is domiciled. Consult note 2 infra.

${ }^{2}$ Attack may be waged in various ways, and may be initiated by the moving party or introduced as a defense. E.g., Cook v. Cook, 342 U.S. 126 (1951) (action for annulment by subsequent spouse); In re Estate of Day, 7 Ill. 2d 348, 131 N.E. 2d 50 (1955) (probate of will by legatee of subsequent spouse); Williams v: North Carolina II, 325 U.S. 226 (1945) (crimina] 